\title{
SPIRITUALITAS KERJA DAN KOMITMEN ORGANISASI PADA PEGAWAI NEGERI SIPIL (PNS)
}

\section{Rezqa Putra Pobri \& Eka Dian Aprilia}

Fakultas Kedokteran, Universitas Syiah Kuala, Jl. Tgk Tanoh Abee, Kopelma Darussalam 23111,Aceh, Indonesia

Korespondensi: eka.aprilia@unsyiah.ac.id

WORK SPIRITUALITY AND ORGANIZATIONAL COMMITMENT IN Manuscript type: Original Research CIVIL OFFICERS

\begin{abstract}
Previous studies showed that the work quality of civil servants in Indonesia is among the lowest compared to other South East Asian countries. Existing literature suggests that individual commitment to organization and work spirituality may contribute to an individual's quality of work. This study aimed to examine this relationship by investigating the relationship between work spirituality and organizational commitment of civil servants in Banda Aceh. A total of 323 civil servants in Banda Aceh were participated in the study and were administered two scales: The Spirit at Work Scale (SAWS) and Organizational Commitment Questionnaire (OCQ) to measure their work spirituality and organizational commitment, respectively. The result found that work spirituality played a significant contribution in increasing organizational commitment of civil servants in Banda Aceh.
\end{abstract}

\section{Article history:}

Received 4 February 2019

Received in revised form 9 July 2019

Accepted 10 September 2019

Available online 5 December 2020

Keywords:
civil servant
organizational commitment
spirituality of work

\begin{abstract}
Abstrak
Studi sebelumnya menunjukkan bahwa kualitas kerja Pegawai Negeri Sipil (PNS) Indonesia berada di bawah negara-negara Asia tenggara lainnya. Tinjauan literatur menunjukkan bahwa komitmen individu terhadap organisasi dan spiritualitas kerja mungkin dapat berkontribusi terhadap kualitas kerja seseorang. Penelitian ini bertujuan untuk mengetahui hubungan antara spiritualitas kerja dan komitmen organisasi pada PNS di Banda Aceh. Sebanyak 323 pegawai negeri sipil di Banda Aceh berpartisipasi dalam studi ini, di mana mereka diminta mengisi skala Spirit at Work Scale (SAWS) dan Organizational Commitment Questionnaire (OCQ) untuk mengukur spiritualitas kerja dan komitmen organisasi mereka. Hasil menunjukkan bahwa spiritualitas kerja memiliki kontribusi yang signifikan untuk meningkatkan komitmen organisasi.
\end{abstract}

Kata Kunci: komitmen organisasi, Pegawai Negeri Sipil (PNS), spiritualitas kerja

\section{Dampak dan Implikasi dalam Konteks Ulayat}

Penelitian ini menunjukkan signifikannya peran nilai-nilai khas suatu masyarakat dalam kehidupan organisasi, khususnya di Aceh. Salah satu faktor pendukung spiritualitas di Aceh adalah agama. Studi ini bisa menjadi acuan dalam mengoptimalkan beragam nilai spiritualitas kerja yang terkandung di masyarakat. Penguatan nilai spiritualitas kerja juga lebih bersifat kontekstual, sehingga manfaat dan evaluasinya bisa lebih spesifik. Penelitian selanjutnya dapat merujuk pada hasil studi ini untuk mengungkap nilai khas masyarakat daerah lain yang potensial bagi peningkatan komitmen organisasi. 


\section{PENDAHULUAN}

Pekerjaan telah menjadi salah satu kepentingan utama dalam kehidupan manusia saat ini yang berfungsi sebagai pendukung kehidupan ekonomi (Abdurrahman \& Agustini, 2011). Salah satu pekerjaan yang banyak diminati oleh penduduk di Indonesia adalah pekerjaan sebagai Pegawai Negeri Sipil (PNS) (Nathabradja, 2013). Menurut Undang-Undang Republik Indonesia nomor 43 Tahun 1999, PNS adalah unsur aparatur negara, abdi negara, dan abdi masyarakat yang sedia dan taat kepada Pancasila, Undang-Undang Dasar 1945, negara, dan pemerintah dalam menyelenggarakan tugas pemerintahan dan pembangunan (Shelviana, 2015). Selain mendapatkan gaji, PNS juga mendapatkan jaminan hari tua (pensiun), jaminan kesehatan, asuransi kecelakaan, tunjangan anak dan istri, dan fasilitas kantor,seperti mobil dinas, dan lain-lain (Keban, 2004).

Setiap PNS wajib melaksanakan tugasnya secara profesional, bertanggung jawab, adil, bersih, dan bebas dari KKN (Korupsi, Kolusi, dan Nepotisme) (Shelviana, 2015). Rasio jumlah PNS dari populasi penduduk di Indonesia adalah sebesar 1.9\% yang artinya ada 1-2 orang yang melayani setiap 100 orang penduduk Indonesia ("Ini perbandingan jumlah PNS RI dengan negara tetangga”, 2014). Namun, lebih dari 1.5 juta diantaranya masih memiliki kompetensi yang kurang memadai, sehingga memengaruhi kinerja dan pelayanan kepada publik (Sabandar, 2017).

Berdasarkan indeks membangun aparatur negara yang dilakukan oleh Komisi Aparatur Sipil Negara (KASN), kualitas dan kinerja PNS Indonesia memperoleh nilai 46 dari 100. Nilai tersebut masih berada di bawah nilai yang diperoleh negara di Asia Tenggara lain, yakni Filipina, Thailand, Malaysia, dan Singapura. Bahkan, Singapura saat ini menjadi negara dengan kualitas dan kinerja PNS terbaik kedua di dunia (Deny, 2016).

Kinerja PNS yang masih belum sesuai dengan harapan yang diinginkan tentu tidak terlepas dari berbagai faktor yang memengaruhinya (Suwardi \& Utomo, 2011). Salah satu yang memengaruhi kinerja individu adalah komitmen individu terhadap organisasinya (Amilin \& Dewi, 2008). Hal tersebut juga sejalan dengan hasil penelitian yang dilakukan oleh Fauzan dan Sumiyati (2015) yang menunjukkan bahwa komitmen organisasi berpengaruh terhadap kinerja individu di dalam organisasi.

Komitmen organisasi didefinisikan sebagai kondisi psikologis yang mengikat individu dengan organisasinya (Liwun \& Prabowo, 2015) yang merupakan suatu keadaan yang ada dalam diri pegawai yang dapat memengaruhi sikap dan perilaku pegawai (Riyadiningsih, 2012), di mana hal tersebut berasal dari pengalaman kerja, pelaksanaan tanggung jawab, dan pengetahuan akan 
hasil kerja (Lumbanraja \& Nizma, 2010). Komitmen organisasi memerlukan suatu pengorbanan dan pengabdian individu terhadap organisasinya, sehingga dapat diartikan sebagai kesediaan untuk melakukan apa saja yang telah diputuskan oleh organisasinya (Buhali \& Margaretha, 2013). Suatu organisasi membutuhkan pegawai yang memiliki komitmen organisasi yang tinggi agar organisasi tersebut dapat terus bertahan serta dapat meningkatkan jasa dan produk yang dihasilkannya (Chairy, 2002). Komitmen organisasi ini penting, bahkan negara-negara maju, seperti Amerika Serikat, Inggris, dan Rusia masih memiliki tingkat komitmen organisasi karyawan masing- masing sebesar 30\%, 17\%, dan 19\% (Crabtree, 2013).

Pegawai dengan komitmen yang tinggi terhadap organisasinya menunjukkan sikap: 1) menerima nilai-nilai dan tujuan yang ingin dicapai organisasi, 2) berusaha secara sungguh-sungguh atas nama organisasinya, serta 3) berkeinginan untuk mempertahankan diri agar selalu berada di lingkungan organisasi dan merasa sebagai bagian dari organisasi (Zagladi, 2004). Sementara itu, pegawai dengan komitmen rendah akan menunjukkan kinerja yang rendah karena kurangnya rasa tanggung jawab terhadap organisasi, memiliki riwayat kehadiran yang bermasalah (Fauzan \& Sumiyati, 2015) dan bermalas-malasan (Rahayu, 2012).

Farisi (2017) mengatakan bahwa PNS yang tidak memiliki komitmen atau memiliki komitmen rendah terhadap organisasinya cenderung menunjukkan perilaku negatif, seperti korupsi, pemungutan liar, tidak disiplin, dan menunda pekerjaan. Selain itu, ada yang melakukan pemalsuan dokumen dan penyalahgunaan wewenang (Redaksi, 2014). Beberapa perilaku negatif tersebut juga dilakukan oleh oknum PNS di Aceh, salah satunya adalah korupsi, di mana terdapat empat PNS Dinas Pendapatan dan Kekayaan Aceh (DPKA) yang ditetapkan sebagai tersangka kasus korupsi pengadaan mobil pemadam kebakaran untuk Pemerintah Kota Banda Aceh karena spesifikasi mobil yang diberikan tidak sesuai dengan spesifikasi mobil yang disepakati pada saat perencanaan pengadaan mobil tersebut (Afif, 2015). Perilaku negatif lainnya yang terjadi adalah pemungutan liar. Tim Satuan Tugas Sapu Bersih Pungutan Liar (Satgas Saber Pungli) Polisi Daerah (Polda) Aceh melakukan Operasi Tangkap Tangan (OTT) terhadap dua oknum PNS Dinas Cipta Karya Aceh dengan barang bukti Rp 15,5 juta di kantin dinas tersebut yang sedang melakukan pemungutan liar pada proyek pembangunan rumah ibadah di Aceh Besar (Husni, 2016).

Adapun di Banda Aceh, contoh perilaku negatif juga dilakukan oleh oknum PNS, di antaranya adalah tidak disiplin, seperti kasus saat Personel Satuan Polisi Pamong Praja (Satpol PP) Provinsi Aceh berhasil merazia lima PNS yang bolos atau berada di luar kantor saat jam dinas. Mereka berasal dari beragam instansi, seperti rumah sakit, Dinas Kesehatan Aceh, Badan 
Penanggulangan Bencana Aceh (BPBA), Dinas Perikanan Aceh, dan Dinas Perindustrian dan Perdagangan (Disperindag) Kota Banda Aceh (Bakri, 2017). Selanjutnya, sebanyak tujuh PNS Kota Banda Aceh akan diberhentikan secara tidak hormat karena tidak masuk kerja lebih dari 46 hari tanpa ada kabar ("7 PNS di Banda Aceh dipecat akibat kerap mangkir dari tugas", 2014).

Perilaku negatif yang dilakukan oleh oknum PNS tersebut secara tidak langsung akan mencoreng citra PNS lainnya dan citra instansi karena jika perilaku negatif tersebut tidak diantisipasi segera, maka dapat memperluas dan mempertebal citra negatif yang sudah ada (Wirakusuma, 2014). Hingga saat ini, opini masyarakat terhadap PNS cenderung negatif. Hal itu tercermin lewat berbagai ekspresi, seperti demonstrasi, opini media massa, maupun keluhankeluhan melalui surat (“Kikis citra buruk, PNS harus kerja serius”, 2011). Perilaku negatif tersebut muncul mungkin disebabkan oleh rendahnya komitmen kerja terhadap organisasinya (Farisi, 2017).

Komitmen para PNS terhadap organisasinya tersebut perlu ditingkatkan dengan sejumlah cara. Salah satu upaya yang dapat dilakukan adalah dengan menjunjung tinggi nilai-nilai spiritualitas di lingkungan kerja atau lebih dikenal dengan spiritualitas kerja (Santiago, 2007). Spiritualitas kerja merupakan perpaduan antara nilai-nilai kehidupan yang dianut kedalam perilaku kerja (Ashmos \& Duchon, 2000). Menurut Nurtjahjanti (2010), spiritualitas kerja diartikan sebagai ekspresi keinginan diri untuk mencari makna dan tujuan dalam bekerja dengan menerapkan nilainilai kehidupan yang sangat dipegang oleh pegawai. Spiritualitas kerja tidak berkaitan dengan agama tertentu (Laabs, 1995; Cavanagh, 1999), melainkan dapat berdasar pada prinsip pribadi dan filsafat yang dipercaya oleh masing-masing pribadi (Ashmos \& Duchon, 2000; Mitroff \& Denton, 1999).

Banda Aceh sebagai salah satu kota yang memiliki visi menjadi sebagai model kota madani mengharapkan masyarakat dan pegawainya untuk menjunjung tinggi nilai-nilai norma yang berlaku (Multazam, 2014). Keadaan ini sangat mendukung terciptanya lingkungan dengan spiritualitas kerja karena dengan adanya spiritualitas di tempat kerja di harapkan akan membuat pegawai merasakan makna dan tujuan dalam pekerjaannya (Litzey, 2003). Makna dan tujuan yang telah diperoleh akan berdampak pada upaya pegawai dalam mewujudkan nilai dan tujuan organisasinya yang merupakan bagian dari komitmen seorang pegawai terhadap organisasinya (Dehagi dkk., 2012)

Shahbaz dan Ghafoor (2015) juga menjelaskan bahwa dengan diperolehnya makna dan tujuan dari pekerjaan melalui adanya spiritualitas kerja, pegawai akan senantiasa melibatkan segenap fisik, mental, emosional, dan spiritual mereka dalam melakukan pekerjaan dan selalu berusaha secara sungguh-sungguh atas nama organisasinya. Berusaha secara sungguh-sungguh atas 
nama organisasinya juga merupakan bentuk sikap yang menunjukkan bahwa pegawai tersebut memiliki komitmen terhadap organisasinya (Zagladi, 2004). Lips-Wiersma (2002) menambahkan bahwa pegawai yang memiliki spiritualitas kerja akan memiliki arah saat menghadapi pemasalahan kerja, tekanan, dan penurunan semangat. Selain itu, spiritualitas kerja akan membentuk sikap jujur, tulus, menghargai sesama, dan berani mengambil resiko (Petchsawang \& Duchon, 2009). Lebih lanjut, spiritualitas kerja juga mampu meningkatkan kepuasan kerja (Yousef, 2000; Fleming, 2003), memperkuat kepercayaan dan ketulusan saat bekerja (Fleming, 2003), memperoleh kesenangan dan kebahagiaan saat bekerja (Krishnakumar \& Neck, 2002), serta secara keseluruhan akan meningkatkan kinerja organisasi (Mitroff \& Denton, 1999; Neck \& Milliman, 1994). Sementara itu, pegawai yang tidak memiliki spiritualitas kerja atau spiritualitas kerjanya rendah akan mudah bosan terhadap pekerjaan dan mudah tertekan karena tuntutan pekerjaan (Zamor, 2003).

Hasil penelitian Dehagi dkk. (2012) menyatakan bahwa spiritualitas kerja merupakan salah satu factor penting yang menentukan tingkat komitmen organisasi pegawai. Spiritualitas kerja mendorong timbulnya emosi positif yang berpengaruh terhadap komitmen pegawai dalam suatu organisasi (Rego \& Cunha, 2008). Penelitian lainnya juga menunjukkan hasil yang serupa bahwa terdapat hubungan yang positif dan signifikan antara spiritualitas kerja dengan komitmen organisasi pegawai, di mana komitmen pegawai dapat ditingkatkan dengan menerapkan spiritualitas di tempat kerja (Shahbaz \& Ghafoor, 2015).

\section{Spiritualitas Kerja}

Kinjerski dan Skrypnek (2006) mendefinisikan spiritualitas kerja sebagaiketerlibatan sisi kognitif, interpersonal, spiritual, dan kepercayaan yang bersifat mistis pada individu dalam penerapan perilaku kerja. Ada empat aspek yang membentuk spiritualitas kerja yang meliputi: 1) ketertarikan kerja, yang ditandai dengan pemaknaan secara mendalam terhadap kesejahteraan, memiliki keyakinan jika pekerjaan yang dipilih memiliki arti dan memiliki tujuan yang lebih tinggi, adanya kesadaran akan keselarasan antara nilai-nilai dan keyakinan pribadi dengan pekerjaan yang dipilih dan tidak ikut-ikutan, 2) hubungan spiritual, yang ditandai dengan rasa koneksi ke sesuatu yang lebih besar dari diri sendiri, 3) rasa kebersamaan, yang ditandai dengan perasaan keterhubungan kepada orang lain dan tujuan bersama, dan 4) pengalaman bersifat mistis yang ditandai dengan keadaan positif disebabkan oleh energi atau semangat, rasa kesempurnaan terhadap segala hal, mampu melampaui kebiasaan baik dan buruk, dan pengalaman sukacita di dalam hidup, serta rasa memiliki kebahagiaan. Menurut Kinjerski dan Skrypnek (2006), terdapat empat aspek 
spiritualitas kerja, yaitu: ketertarikankerja (engaging work), hubungan spiritual (spiritual connection), rasa kebersamaan (sense of community), dan pengalaman bersifat mistis (mystical experience).

Ketertarikan kerja merupakan pemaknaan secara mendalam terhadap kesejahteraan, memiliki keyakinan jika pekerjaan yang dipilih memiliki arti dan memiliki tujuan yang lebih tinggi, adanya kesadaran akan keselarasan antara nilai-nilai dan keyakinan pribadi dengan pekerjaan yang dipilih, dan tidak ikut-ikutan memilih pilihan orang lain. Hubungan spiritual berkaitan dengan perasaan memiliki hubungan terhadap kekuatan yang lebih besar dari diri sendiri. Rasa kebersamaan ialah perasaan memiliki hubungan dengan orang lain dan memiliki tujuan yang sama. Terakhir, pengalaman bersifat mistis yaitu keadaan positif yang disebabkan oleh energi atau semangat, merasa sempurna, mampu melampaui kebiasaan baik atau buruk, pengalaman terhadap segala sukacita yang dialami, dan perasaan bahagia.

Adapun faktor yang memengaruhi spiritualitas kerja diantaranya adalah jenis kelamin (Sharique dkk., 2012) dan agama (bagi yang memiliki) (Twigg \& Parayitam, 2006). Selain itu, terdapat faktor rasa memiliki tujuan dan kebermaknaan di dalam pekerjaan yang digerakkan oleh misi serta nilai organisasi yang berlandaskan hati nurani. Faktor lainnya adalah kenyamanan, kebebasan, dan merasakan perkembangan diri yang didukung oleh kepedulian organisasi terhadap pemberdayaan anggota organisasi (Yogatama \& Widyarini, 2015).

\section{Komitmen Organisasi}

Komitmen organisasi didefinisikan sebagai keadaan psikologis yang mengikat individu terhadap organisasi yang diungkapkan melalui tiga aspek, yaitu komitmen afektif (affective commitment), komitmen lanjutan (continuance commitment), dan komitmen normatif (normative commitment) (Allen \& Meyer, 1990). Komitmen afektif adalah komitmen yang muncul karena adanya keterikatan psikologis individu atau karyawan terhadap organisasinya. Komitmen berkelanjutan adalah komitmen yang berkaitan dengan pertimbangan untung-rugi meninggalkan organisasi. Komitmen normatif adalah komitmen yang terbentuk berkaitan dengan persepsi individu atau karyawan bahwa sebagai anggota organisasi, mereka merasa mempunyai kewajiban untuk tetap bertahan di organisasinya.

Faktor-faktor yang memengaruhi komitmen afektif (affective commitment),yaitu karakteristik pribadi, karakteristik jabatan, pengalaman kerja, dan karakteristik struktural (besarnya organisasi, kehadiran serikat kerja, luasnya kontrol, dan sentralisasi otoritas). Dari keempat faktor 
tersebut, yang paling memengaruhi komitmen afektif adalah pengalaman kerja khususnya terkait kebutuhan psikologis dari organisasi, seperti perasaan nyaman saat bekerja dan pengalaman dalam menjalankan peran kerja. Sedangkan faktor-faktor yang memengaruhi komitmen berkelanjutan (continuance commitment), meliputi besar-kecilnya investasi yang telah diberikan pegawai terhadap organisasi dan persepsi terhadap risiko yang ditanggung jika meninggalkan organisasi. Adapun faktor-faktor yang memengaruhi komitmen normatif yaitu pengalaman pegawai sebelum bekerja di organisasi, baik yang berasal dari didikan keluarga, maupun sosial budaya di lingkungan hidup pegawai, serta pengalaman sosialisasi selama bekerja dalam organisasi (Allen \& Mayer, 1990).

\section{Tujuan Studi}

Penelitian ini bertujuan untuk melihat dan menentukan peran spiritualitas kerja (sebagai variabel independen simultan) terhadap komitmen organisasi.

\section{METODE}

\section{Partisipan}

Populasi PNS yang ada di Kota Banda Aceh berdasarkan data tahun 2017 berjumlah 4,436 orang, terdiri dari 1,539 laki-laki dan 2,897 perempuan (Badan Kepegawaian dan Pengembangan Sumber Daya Manusia Kota Banda Aceh, 2017). Adapun kriteria sampel pada penelitian ini adalah: 1) tercatat sebagai PNS aktif yang bekerja di Banda Aceh, dan 2) bersedia menjadi responden penelitian. Dalam menentukan jumlah sampel penelitian, peneliti menggunakan pedoman tabel Issac dan Michael (Sugiyono, 2013). Berdasarkan tabel tersebut, jumlah sampel penelitian dengan taraf kesalahan lima persen dari populasi sebanyak 4,436 orang adalah 323 sampel.

Penentuan sampel pada penelitian ini menggunakan teknik snowball sampling. Teknik snowball sampling merupakan suatu metode untuk mengidentifikasi, memilih, dan mengambil sampel dalam suatu jaringan atau rantai hubungan yang menerus. Teknik ini digunakan karena sesuai dengan keadaan sampel di lapangan guna memenuhi jumlah sampel penelitian yang dibutuhkan, di mana sampel PNS pada penelitian ini terbagi ke dalam instansi atau dinas yang tersebar di seluruh wilayah Banda Aceh. Oleh karena itu, akan sangat sulit bagi peneliti untuk memenuhi jumlah sampel yang dibutuhkan jika menggunakan teknik sampling yang lain. Teknik sampling ini membebaskan peneliti untuk memilih siapapun untuk dijadikan sampel penelitian, asalkan sesuai dengan kriteria yang sudah ditentukan. 
Profil partisipan terbagi ke dalam data demografi dan deskripsi skor partisipan pada masingmasing variabel. Tabel 1 merangkum profil demografis partisipan.

Tabel 1.

Data Demografi Subjek Penelitian

\begin{tabular}{cccc}
\hline Deskripsi Subjek & Kategori & Jumlah & Persentase (\%) \\
\hline Usia (tahun) & $18-40$ & 194 & 60.06 \\
& $41-60$ & 129 & 39.94 \\
\hline \multirow{2}{*}{ Jenis kelamin } & Laki-laki & 189 & 58.51 \\
& Perempuan & 134 & 41.49 \\
\hline \multirow{2}{*}{ Lama bekerja (tahun) } & $0-6$ & 69 & 21.36 \\
& $7-15$ & 168 & 52.01 \\
& $>15$ & 86 & 26.63 \\
\hline \multirow{3}{*}{ Pendidikan } & SDN & 14 & 4.33 \\
& SMPN & 2 & .62 \\
& SMAN/SMKN & 27 & 8.36 \\
& SMA & 20 & 6.19 \\
& D3 & 19 & 5.88 \\
& S1 & 248 & 76.78 \\
& S2 & 36 & 11.14 \\
\hline
\end{tabular}

\section{Desain}

Penelitian ini merupakan penelitian kuantitatif dengan jenis penelitian korelasi untuk melihat hubungan spiritualitas kerja dengan komitmen organisasi PNS di Banda Aceh. Partisipan penelitian ini diberikan dua skala psikologi. Skala pertama, yaitu skala adaptasi Spirit at Work Scale (SAWS) yang dikembangkan oleh Kinjerski dan Skrypnek (2006). Skala ini memiliki 18 butir pernyataan dengan menggunakan skala model likert yang terdiri dari enam pilihan jawaban. Skala kedua diadaptasi dari Organizational Commitment Questionnaire (OCQ) yang dikembangkan oleh Allen dan Meyer (1990). Skala ini memiliki 24 butir pernyataan dengan menggunakan skala model Likert yang terdiri dari tujuh pilihan jawaban. Data dikumpulkan menggunakan versi Bahasa Indonesia dari skala yang relevan. Proses adaptasi dilakukan dengan melakukan terjemahan kembali ke skala dan memiliki tiga ahli dalam psikologi industri dan psikometrik untuk meninjau kesesuaian terjemahan dan untuk mengantisipasi bias budaya mengingat kekhususan budaya skala. Ahli penilaian dilakukan oleh panel ahli yang profesional di bidang psikologi. Jadi, dua pengukuran dapat mewakili konstruk, sehingga barang-barang di alat ukur tidak berubah. 


\section{Prosedur}

Pelaksanaan penelitian dilakukan dengan menyebarkan langsung skala penelitian ke masingmasing instansi yang sudah disepakati. Penelitian berlangsung selama kurang lebih 3 bulan karena peneliti kesulitan untuk memenuhi jumlah sampel yang dibutuhkan karena kesibukan masingmasing PNS, sehingga membutuhkan banyak waktu hingga akhirnya jumlah sampel yang dibutuhkan terpenuhi. Pengisian skala menggunakan metode paper and pencil dengan didahului pemberian penjelasan tentang prosedur penelitian dan pengisian inform consent.

\section{Teknik Analisis}

Data yang diperoleh dari penelitian dianalisis menggunakan teknik One-Sample Kolmogorov-Smirnov Test untuk menguji normalitas data dan uji linieritas dari Anova. Selanjutnya, dilakukan pengujian hipotesis menggunakan teknik parametrik yaitu Pearson Product Moment Correlation denganmenggunakan program SPSS version 20.0 for Windows.

\section{ANALISIS DAN HASIL}

Peneliti melakukan analisis deskriptif terhadap skor spiritualitas kerja partisipan. Berdasarkan hasil statistik data penelitian, analisis deskriptif secara hipotetis menunjukkan bahwa jawaban maksimal untuk variabel spiritualitas kerja adalah 108 dan minimal $18(M=63.000 ; S D=$ 15.000), sedangkan pada data empiris menunjukkan bahwa jawaban maksimal 106 dan minimal 58 $(M=85.850 ; S D=8.450)$. Deskripsi data hasil penelitian tersebut dapat dijadikan batasan dalam pengkategorian sampel penelitian yang terdiri dari dua kategori, yaitu tinggi dan rendah. Pembagian kategori sampel dalam penelitian ini menggunakan metode pertimbangan eror standar dalam pengukuran. Metode ini menggunakan kisaran skor atau fluktuasi skor rata-rata (Azwar, 2013). Hasil kategorisasi ditunjukkan dalam Tabel 2.

Tabel 2.

Kategorisasi Spiritualitas Kerja pada PNS Banda Aceh

\begin{tabular}{cccc}
\hline Skor & Kategori & Jumlah & Persentase (\%) \\
\hline $\mathrm{X}<56$ & Rendah & 0 & 0 \\
$56 \leq \mathrm{X}<70$ & Tak terkategorisasi & 6 & 1.86 \\
$70 \leq \mathrm{X}$ & Tinggi & 317 & 98.14 \\
\hline
\end{tabular}


Berdasarkan tabel di atas, terlihat bahwa tidak ada subjek yang termasuk dalam kategori rendah, 317 subjek termasuk dalam kategori tinggi, dan enam subjek lainnya tidak terkategorisasikan. Hal ini karena skor subjek berada pada batas kisaran skor atau fluktuasi skor rata-rata, sehingga tidak terkategorisasikan tinggi atau rendah (tidak terkategori). Kategori rendah pada tabel di atas menunjukkan spiritualitas kerja yang rendah, sebaliknya kategori tinggi menunjukkan tingkat spiritualitas kerja yang tinggi.

Terakhir, analisis deskriptif terhadap variable komitmen organisasi menunjukkan bahwa secara hipotesis, jawaban maksimal untuk variabel komitmen organisasi adalah 168 dan minimal 24 $(M=96.000 ; S D=24.000)$, sedangkan pada data empiris menunjukkan bahwa jawaban maksimal, ialah 159 dan minimal adalah $82(M=126.700 ; S D=16.000)$. Dengan metode yang sama dengan pada variabel spiritualitas kerja, diperoleh kategorisasi sebagaimana ditunjukkan pada Tabel 3 di bawah.

Tabel 3.

Kategorisasi Komitmen Organisasi pada PNS Banda Aceh

\begin{tabular}{cccc}
\hline Skor & Kategori & Jumlah & Persentase (\%) \\
\hline $\mathrm{X}<85$ & Rendah & 2 & .62 \\
$85 \leq \mathrm{X}<107$ & Tak terkategorisasi & 40 & 12.38 \\
$107 \leq \mathrm{X}$ & Tinggi & 281 & 87 \\
\hline
\end{tabular}

Sebagaimana ditunjukkan dalam tabel, 281 subjek termasuk dalam kategori komitmen organisasi tinggi, dua subjek termasuk dalam kategori komitmen organisasi rendah, dan 40 subjek lainnya tidak terkategorisasikan. Hal ini karena skor subjek berada pada batas kisaran skor atau fluktuasi skor rata-rata, sehingga tidak terkategorisasikan tinggi atau rendah (tidak terkategori). Kategori rendah pada tabel di atas menunjukkan komitmen organisasi yang rendah, sebaliknya kategori tinggi menunjukkan tingkat komitmen organisasi yang tinggi.

\section{Uji Asumsi}

Hasil uji asumsi menunjukkan bahwa data berdistribusi normal dan linier. Hal ini dilihat dari hasil analisis yang menunjukkan bahwa pada variabel spiritualitas kerja diperoleh hasil $\left(Z_{K-S}=\right.$ $1.210 ; p=.106)$. Selanjutnya, pada variablel komitmen organisasi diperoleh nilai $\left(Z_{K-S}=1.297 ; p=\right.$ .069). Hasil uji linieritas menunjukkan nilai signifikansi pada linieritas $(p=.003)$. Hasil tersebut 
menunjukkan bahwa terdapat hubungan yang linier antara variabel spiritualitas kerja dan komitmen organisasi.

\section{Uji Hipotesis}

Uji hipotesis menggunakan analisis korelasi Pearson dikarenakan data berdistribusi secara normal. Hasil analisis menunjukkan bahwa terdapat korelasi positif $(r=.163 ; p=.003)$ antara spiritualitas kerja dengan komitmen organisasi pada PNS di Banda Aceh.

\section{DISKUSI}

Studi ini menunjukkan bahwa terdapat hubungan antara spiritualitas kerja dan komitmen organisasi. Hal tersebut menunjukkan bahwa semakin tinggi spiritualitas kerja pada PNS di Banda Aceh, semakin tinggi komitmen organisasinya, dan begitu pula sebaliknya. Hal ini sejalan dengan hasil penelitian yang dilakukan oleh Shahbaz dan Ghafoor (2015) terhadap pegawai penyuplai air bersih di Pakistan yang juga menunjukkan bahwa spiritualitas kerja dapat meningkatkan komitmen organisasi pada pegawai tersebut. Penelitian lain yang dilakukan oleh Rego dan Cunha (2008) terhadap 361 individu yang berasaldari 154 organisasi di Portugal juga menemukanhasil yang sama, yaitu pegawai dengan spiritualitas kerja yang tinggi memiliki komitmen organisasi yang tinggi pula.

Hasil penelitian oleh Dehagi dkk. (2012) yang dilakukan terhadap pegawai di Amerika juga menunjukkan bahwa terdapat hubungan yang positif antara spiritualitas kerja dengan komitmen organisasi dan disebutkan bahwa spiritualitas kerja merupakan salah satu faktor penting yang menciptakan komitmen organisasi di instansi. Penelitian yang dilakukan oleh Haryokusumo (2015) terhadap 130 pegawai dari enam organisasi berbeda juga menunjukkan hasil yang sama, yaitu terdapat hubungan yang positif antara spiritualitas kerja dengan komitmen organisasi, di mana spiritualitas kerja mewadahi terbentuknya komitmen organisasi pada individu.

Terdapat beberapa faktor yang juga mempengaruhi komitmen organisasi, yaitu budaya keterbukaan, kepuasan kerja, kesempatan personal untuk berkembang, arah gerak organisasi atau instansi, dan penghargaan hasil kerja yang sesuai (Stum, 1998).

Selanjutnya, berdasarkan analisis deskriptif, jika dilihat dari segi spiritualitas kerjanya, 98.14\% PNS di Banda Aceh memiliki tingkat spiritualitas kerja yang tinggi dan nol persen yang memiliki tingkat spiritualitas kerja rendah. Besarnya jumlah sampel yang memiliki spiritualitas kerja yang tinggi salah satunya disebabkan oleh faktor agama, di mana agama juga dapat 
membentuk karakter yang baik pada individu dan mendukung adanya spiritualitas kerja (Twigg \& Parayitam, 2006).

Spiritualitas kerja membentuk adanya harga diri dan kebahagian dalam diri individu. (Krishnakumar \& Neck, 2002). Dengan begitu, hasilnya adalah individu akan selalu total dalam bekerja dan memandang pekerjaan bukan hanya sebagai kewajiban yang dituntaskan, namun lebih dari sekadar kewajiban. Perilaku ini membentuk kelekatan antara individu dengan organisasi yang pada akhirnya berdampak pada komitmen individu terhadap organisasinya (Gavin \& Mason, 2004). Lips-Wiersma (2002) menambahkan bahwa pegawai yang memiliki spiritualitas kerja akan memiliki arah saat menghadapi pemasalahan kerja, tekanan, dan penurunan semangat. Selain itu, spiritualitas kerja akan membentuk sikap jujur, tulus, menghargai sesama, dan berani mengambil resiko (Petchsawang \& Duchon, 2009). Lebih lanjut, spiritualitas kerja juga mampu meningkatkan kepuasan kerja (Fleming, 2003; Yousef, 2000), memperkuat kepercayaan dan ketulusan saat bekerja (Fleming, 2003), memperoleh kesenangan dan kebahagiaan saat bekerja (Krishnakumar \& Neck, 2002), serta secara keseluruhan akan meningkatkan kinerja organisasi (Mitroff \& Denton, 1999; Neck \& Milliman, 1994). Sebaliknya, pegawai dengan spiritualitas kerja rendah akan mudah bosan terhadap pekerjaan dan mudah tertekan karena tuntutan pekerjaan (Zamor, 2003).

Berdasarkan segi komitmen organisasinya, hasil analisis deskriptif menunjukkan bahwa terdapat $87 \%$ PNS di Banda Aceh memiliki tingkat komitmen organisasi yang tinggi dan .62\% memiliki tingkat komitmen organisasi yang rendah. Besarnya jumlah sampel yang memiliki komitmen organisasi yang tinggi berarti sudah banyak PNS Banda Aceh yang memiliki perasaan positif terhadap organisasinya. Tingginya komitmen yang dimiliki oleh anggota organisasi akan membuat organisasi lebih mampu bersaing dikarenakan umumnya karyawan yang memiliki komitmen tinggi cenderung memiliki kreasi dan inovasi (Miftahun \& Sugiyanto, 2010). Adanya sebagian kecil PNS yang berkomitmen rendah membuktikan bahwa masih ada oknum PNS yang tidak mengetahui seberapa besar kontribusinya terhadap instansi dan tidak mengetahui harus berbuat apa untuk memajukan instansinya, sehingga terkesan hanya menerima gaji saja setiap bulannya (Sakina, 2009), serta adanya oknum PNS yang masih melakukan beberapa perilaku negatif seperti yang telah peneliti paparkan di latarbelakang penelitian ini.

Selanjutnya, berdasarkan karakteristik usia subjek, peneliti menggolongkan usia berdasarpada masa perkembangan manusia yang dikemukakanoleh Hurlock (1994), diantaranya masa dewasa awal dengan rentang usia 18-40 tahun dan masa dewasa madya dengan usia berkisar 41-60 tahun. Jika dilihat berdasarkan perbandingan jumlah, maka dapat dikatakan bahwa kedua 
golongan tersebut memiliki komitmen organisasi yang sama-sama tinggi karena jumlah sampel antara dua golongan tersebut tidak seimbang. Hasibuan (2003) berpendapat bahwa usia individu memengaruhi kondisi fisik, mental, kemampuan kerja, dan tanggung jawab dalam bekerja. Ini menunjukkan bahwa usia berkorelasi positif dengan komitmen organisasi. Hasil ini didukung oleh penelitian sebelumnya yang dilakukan oleh Supriyono (2006) yang meneliti para manajer di Indonesia. Hasilnya juga menunjukkan bahwa usia memiliki hubungan positif dengan komitmen organisasi dan menentukan tingkat komitmen organisasi seseorang, di mana komitmen semakin meningkat sesuai dengan usia dan mulai menurun mendekati masa pensiun kerja.

Berdasarkan rentang lama bekerja yang disusun berdasarkan Hadiyani dkk. (2012), terdapat perbedaan komitmen organisasi pada masa kerja 0-6 tahun, masa kerja 7-15 tahun, dan masa kerja lebih dari 15 tahun. Merujuk pada pengkategorian tersebut, subjek dalam penelitian ini digolongkan ke dalam tiga kategori, yaitu lama bekerja 0-6 tahun sebesar 21.36\%, 7-15 tahun sebesar 52.01\%, dan yang tergolong dalam lama bekerja lebih dari 15 tahun sebesar 26.63\%. Hasil penelitian ini menunjukkan bahwa komitmen organisasi tertinggi berada pada lama bekerja 7-15 tahun, karena rentang ini merupakan masa-masa bekerja di mana pegawai masih dalam kondisi memiliki semangat tinggi dan betah dalam bekerja (Marchelia, 2014).

\section{SIMPULAN DAN SARAN}

\section{Simpulan}

Hasil penelitian menunjukkan bahwaterdapat hubungan positif antara spiritualitas kerja dengan komitmen organisasi. Hal ini berarti bahwa semakin tinggi spiritualitas kerja, semakin tinggi pula komitmen organisasi yang dimiliki, dan begitu pula sebaliknya. Hasil penelitian ini juga menunjukkan bahwa mayoritas partisipan memiliki tingkat spiritualitas kerja yang tinggi, begitu pula dengan komitmen organisasinya.

\section{Saran Teoretis}

Kepada peneliti selanjutnya, diharapkan dapat mengembangkan penelitian ini dengan menyertakan faktor-faktor lain yang dapat memengaruhi spiritualitas kerja dan komitmen organisasi, seperti budaya keterbukaan, kepuasan kerja, kesempatan personal untuk berkembang, arah gerak organisasi atau instansi, dan penghargaan hasil kerja. Selanjutnya, bagi peneliti yang ingin melakukan penelitian dengan variabel yang sama, dapat meneliti dengan menggunakan 
metode penelitian kualitatif yang dilakukan dengan wawancara mendalam, sehingga dinamika informasi yang diperoleh dapat lebih terlihat.

Seperti yang telah diketahui, penelitian ini menggunakan metode kuantitatif sehingga sangat mungkin terjadi bias dan sangat kurangnya observasi. Jika memungkinkan, bagi peneliti yang ingin melakukan penelitian dengan variabel yang sama, maka dapat meneliti dengan metode penelitian kualitatif, yaitu dengan wawancara mendalam, sehingga informasi yang diperoleh dapat lebih bervariasi dan dapat mengantisipasi kemungkinan bias positif partisipan.

\section{Saran Praktis}

PNS di Banda Aceh yang telah memiliki spiritualitas kerja yang baik dapat terus mempertahankannya agar tercipta komitmen organisasi yang baik sehingga dapat mempertahankan performainstansi dan menjaga citra instansi di mata masyarakat.

\section{REFERENSI}

7 PNS di Banda Aceh dipecat akibat kerap mangkir dari tugas. (2014, 20 Februari). Detik. http://news.detik.com/berita/2503741/7-pns-di-banda-aceh-dipecat-akibat-kerap-mangkirdari-tugas

Abdurrahman, D., \& Agustini, P. M. (2011). Hubungan kepemimpinan spiritual dan spiritualitas tempat kerja. Dalam Ceha, R. (Eds.). Prosiding Seminar Nasional Penelitian dan PKM: Sosial, Ekonomi, \& Humaniora, $\quad$ 2(1), 527-542. http://repository.unisba.ac.id:8080/bitstream/handle/123456789/609/SNaPP2011_Sartika_F ulltext.PDF?sequence=2\&isAllowed $=\mathrm{y}$

Afif. (2015, 16 Juni). 4 PNS di Aceh jadi tersangka kasus korupsi hibah mobil damkar. Merdeka. https://www.merdeka.com/peristiwa/4-pns-di-aceh-jadi-tersangka-kasus-korupsi-hibahmobil-damkar.html

Allen, N. J., \& Meyer, J. P. (1990). The measurement and antecedents of affective, continuance and normative commitment to the organization. Journal of Occupational Psychology, 63(1). 1-18. https://doi.org/10.1111/j.2044-8325.1990.tb00506.x

Amilin, \& Dewi, R. (2008). Pengaruh komitmen organisasi terhadap kepuasan kerja akuntan publik dengan role stress sebagai variabel moderating. Jurnal JAAI, 12(1).13-24. 
Ashmos, D. P., \& Duchon, D. (2000). Spirituality at work: A conceptualization and measure. Journal of Management Inquiry, 9(2), 134-145. https://doi.org/10.1177/105649260092008

Azwar, S. (2013). Penyusunan skala psikologi (2nd ed.). Pustaka Pelajar.

Badan Kepegawaian dan Pengembangan Sumber Daya Manusia Kota Banda Aceh. (2017). Perbandingan Jumlah PNS Pemerintah Bota Aceh. https://bkpsdm.bandaacehkota.go.id/statistik/

Badan Pusat Statistik. (2015). Kota Banda Aceh dalam angka 2015. Badan Pusat Statistik Kota Banda Aceh.

Bakri. (2017, 8 Maret). SATPOL PP Aceh razia PNS bolos. Serambi News. http://aceh.tribunnews.com/2017/03/08/satpol-pp-aceh-razia-pns-bolos

Buhali, G. A., \& Margaretha, M. (2013). Pengaruh work-family conflict terhadap komitmen organisasi: Kepuasan kerja sebagai variabel mediasi. Jurnal Manajemen Maranatha, 13(1), 15-34. https://doi.org/10.28932/jmm.v13i1.140

Cavanagh, G. F. (1999). Spirituality for managers: Context and critique. Journal of Organizational Change Management, 12(3), 186-99. https://doi.org/10.1177/1350508403010002013

Chairy, L. S. (2002). Seputar komitmen organisasi. [Manuskrip tidak dipublikasikan]. Universitas Indonesia.

Crabtree, S. (2013, 8 Oktober). Worldwide, 13\% of employees are engaged at work. Gallup. https://news.gallup.com/poll/165269/worldwide-employees-engaged-work.aspx

Creswell, J. W. (2012). Educational research: Planning, conducting, and evaluating quantitative and qualitative research (4th ed.). Pearson.

Dehagi, M. R., Goodarzi, M., \& Arazi, Z. K. (2012). The effect of spiritual values on employees' organizational commitment and its models. Procedia Social and Behavioral Sciences, 62, 159-166.

Deny, S. (2016, 25 Mei). Kualitas PNS RI kalah dibanding Filipina dan Thailand. Liputan6. http://bisnis.liputan6.com/read/2515295/kualitas-pns-ri-kalahdibanding-filipina-dan-thailand

Dwianasari, R., \& Mardiasmo. (2004). The effect of the relationship between budgetary participation and decentralization structure on managerial performance: The role of organizational commitment as intervening variable (Empirical study on municipality and regencies in Yogyakarta province). Sosiosains, 17(4), 655-673.

Farisi, M. (2017, 6 Januari). PNS profesional, bukan asal bapak senang. Metro Jambi. http://metrojambi.com/read/2017/01/19/17291/pns-profesional-bukan-asal-bapak-senang 
Fauzan, A. H., \& Sumiyati. (2015). Pengaruh komitmen organisasi terhadap kinerja karyawan PT. Bank Mandiri Tbk area Cirebon. Portal AntologiUniversitas Pendidikan Indonesia, 3(1), 120.

Fleming, J. H. (2003). Relating employee engagement and customer loyalty to business outcomes in the financial service area. Gallup Research Journal, 3(1), 91-101.

Gavin, J. H., \& Mason, R. O. (2004). The virtous organization: The value of happiness in the workplace. Organizational $\quad$ Performance, 379-392. https://doi.org/10.1016/j.orgdyn.2004.09.005

Hadiyani, M. I., Karmiyari, D., \& Ingarianti, T. M. (2012). Prosiding seminar nasional peran budaya organisasi terhadap efektivitas dan efisiensi organisasi, 157-175. http://eprints.umk.ac.id/499/20/Full\%2BProsiding\%2BSemnas\%2BPsi\%2BUMK\%2B2012.c racked.166-184.pdf

Haryokusumo, D. (2015). The effect of workplace spirituality dimensions on organizational commitment with perceived organizational support as a moderating variable. Jurnal Dinamika Manajemen, 6(2), 187-202. https://doi.org/10.15294/jdm.v6i2.4307

Hasibuan, M, S, P. (2003). Manajemen sumber daya manusia. Bumi Aksara.

Hurlock, E. B. (1994). Psikologi perkembangan: Suatu pendekatan sepanjang rentang kehidupan. Erlangga.

Husni, F. (2016, 28 Desember). PPTK dan konsultan pengawas di dinas cipta karya Aceh ditangkap tim saber pungli. Aceh Journal National Network. http://www.ajnn.net/news/pptkdan-konsultas-pengawas-di-cipta-karya-aceh-ditangkap-tim-saber-pungli/index.html

Ini perbandingan jumlah PNS RI dengan negara tetangga. (2014). Detikfinance. https://finance.detik.com/ekonomi-bisnis/2677733/

Keban, Y. T. (2004). Pokok-pokok pikiran perbaikan sistem manajemen SDM PNS di Indonesia. Jurnal Kebijakan dan Administrasi Publik, 8(2), 15-32.

Kikis citra buruk, PNS harus kerja serius. (2011, 2 Januari). Jaringan Pemberitaan Nusantara Negeriku. http://www.jpnn.com/news/kikis-citra-buruk-pns-harus-kerja-serius

Kinjerski, V., \& Skrypnek, B. J. (2006). Measuring the intangible: Development of the spirit at work scale [Paper presentation]. Sixty-fifth Annual Meeting of the Academy of Management. Atlanta. http://www.tofinospa.com/sawscale.pdf 
Krishnakumar, S., \& Neck, C. P. (2002). The what, why and how of spirituality in the workplace. Journal of Managerial Psychology, 17(33), 153-164. https://doi.org/0.1108/02683940210423060

Laabs, J. J. (1995). Balancing spirituality and work. Personel Journal, 74(9), 60-2.

Litzey, C. (2003). Spirituality in the workplace and the implications for employees and organizations. [Tesis tidak dipublikasikan]. University Carbondale.

Liwun, S. B. B., \& Prabowo, H. (2015). Pengaruh keterlibatan kerja dan spiritualitas kerja terhadap komitmen organisasi. Jurnal Psikologi, 8(1), 32-40.

Lips-Wiersma, M. (2002). Analysing the career concerns of spiritually oriented people: Lesson for contemporary organizations. Career Development International, 7(7), 385-397. https://doi.org/10.1108/13620430210449911

Lumbanraja, P., \& Nizma, C. (2010). Pengaruh pelatihan dan karakteristik pekerjaan terhadap prestasi kerja perawat di badan pelayanan kesehatan Rumah Sakit Umum Daerah Langsa. Jurnal Manajemen dan Kewirausahaan, 12(2), 142-154. https://doi.org/10.9744/jmk.12.2.pp.\%20142-155

Marchelia, V. (2014). Stres kerja ditinjau dari shift kerja pada karyawan. Jurnal Ilmiah Psikologi Terapan, 2(1), 130-143.

Mathieu, J. E., \& Zajac, D. M. (1990). A review and meta-analysis of the antecedents, correlates, and consequences of organizational commitment. Psychological Bulletin, 108(2), 171-194. https://doi.org/10.1037/0033-2909.108.2.171

Miftahun, \& Sugiyanto. (2010). Pengaruh dukungan social dan kepemimpinan transformasional terhadap komitmen organisasi dengan mediator motivasi kerja. Jurnal psikologi, 37(1), 94109.

Mitroff, I. I., \& Denton, E. A. (1999). A spiritual audit of corporate America: A hard look at spirituality, religion, and values in the workplace. Sage. https://doi.org/10.1177/004057360 205900127

Multazam. (2014, 26 Juli). Banda Aceh ibu kota serambi mekkah, model kota madani. http://www.mltazam.com/2014/07/banda-aceh-ibu-kota-serambi-mekah-model.html

Nathabradja, I. (2013, 29 Oktober). 10 Pekerjaan yang paling diminati di Indonesia. Inilah. http://teknologi.inilah.com/read/detail/2042468/10-pekerjaan-yang-paling-diminati-diindonesia/5326 
Neck, C. P., \& Milliman, J. F. (1994). Thought self-leadership: Finding spiritual fulfillment in organizational life. Journal of Managerial Psychology, 9(6), 9-16. https://doi.org/10.1108/02683949410070151

Nurtjahjanti, H. (2010). Spiritualitas kerja sebagai ekspresi keinginan diri karyawan untuk mencari makna dan tujuan hidup dalam organisasi. Jurnal Psikologi UNDIP, 7(1), 27-30. https://doi.org/10.14710/jpu.7.1.27-30

Petchsawang, P., \& Duchon, D. (2009). Measuring workplace spirituality in an Asian context. Human Resource Development International, 12(4) 459-468. https://doi.org/10.1080/13678860903135912

Rahayu, W. (2012). Komitmen organisasi pada karyawan di miracle aesthetic clinic di Surabaya. Jurnal Fakultas Psikologi Universitas Ahmad Dahlan Yogyakarta, 1(1), 110-121.

Redaksi. (2014, 13 Maret). BKN laporkan jumlah PNS kumpul kebo dan berbuat asusila. Aceh Journal National Network. https://www.ajnn.net/news/bkn-laporkan-jumlah-pns-kumpulkebo-dan-berbuat-asusila/index.html

Rego, A., \& Cunha, M. P. (2008). Workplace spirituality and organizational commitment: An empirical study. Journal of Organizational Change Management. 21(1), 53-75. https://doi.org/ 10.1108/09534810810847039

Riyadiningsih, H. (2012). Peran kondisi psikologis dan karakteristik pribadi dalam pengembangan kepemimpinan efektif : Sebuah tinjauan konseptual. Seminar Nasional Dan Call For Papers. http://eprints.unisbank.ac.id/id/eprint/281

Sabandar, S. (2017, 4 Januari). Duh, lebih dari 1,5 Juta PNS di Indonesia tak kompeten. Liputan6. http://regional.liputan6.com/read/2695086/duh-lebih-dari-15-juta-pns-di-indonesia-takkompeten

Sakina, N. (2009). Komitmen organisasi karyawan pada pt bank x di Jakarta. Jurnal Psikologi, 7(2), 53-62.

Santiago, J. A. P. (2007). Estudio exploratory iosobre el tema de la spiritual idaden el ambiente laboral. Anales de Psicología, 23(1), 137-146.

Shahbaz, W., \& Ghafoor, M. M. (2015). Workplace spirituality and organizational commitment: A case study of water and sanitation agencies of Punjab, Pakistan. Basic and Applied Research, 24(1), 234-244. 
Sharique, M., Murtaza, S. T., \& Sharif, S. (2012). A comparative study of spirituality between male and female sportspersons of Aligarh Muslim University, Aligarh. Golden Research Thoughts, $1(8)$.

Shelviana, S. (2015). Hubungan disiplin kerja dengan kinerja Pegawai Negeri Sipil (PNS) di Kecamatan Samarinda Ulu Kota Samarinda. E-journal Ilmu Administrasi Negara, 3(4), 19121926.

Stum, D. (1998). Five Ingrendients for an employee retention formula. Journal of Human Resources Focus, 75(9), S9-S10.

Sugiyono. (2013). Metode penelitian pendekatan kuantitatif, kualitatif, dan R\&D. Alfabeta.

Suwardi, \& Utomo, J. (2011). Pengaruh motivasi kerja, kepuasan kerja, dan komitmen organisasional terhadap kinerja pegawai. Jurnal Analisi Manajemen, 5(1), 75-86.

Twigg, N. W., \& Parayitam, S. (2006). Spirit at work: Spiritual typologies as theory builders. Journal of Organizational Culture, Comminication, and Conflict, 10(2), 17-33.

Wirakusuma, K. Y. (2014, 16 April). PNS diminta ubah citra negatif dalam pelayanan masyarakat. Okenews. http://news.okezone.com/read/2014/04/16/337/971453/pns-diminta-ubah-citranegatif-dalam-pelayanan-masyarakat

Yogatama, L. A. M., \& Widyarini, N. (2015). Kajian spiritualitas di tempat kerja pada konteks organisasi bisnis. Jurnal Psikologi, 42(1).

Yousef, D. A. (2000). Organizational commitment as a mediator of the relationship between islamic work ethic and attitudes toward organizational change. Human Relations, 53(4), 513-37. https://doi.org/10.1177/0018726700534003

Zagladi, A. L. (2004). Pengaruh kelelahan emosional terhadap kepuasan kerja dan kinerja dalam pencapaian komitmen organisasional dosen perguruan tinggi swasta. [Disetasi tidak dipublikasikan]. Universitas Brawijaya.

Zamor, J. C. G. (2003). Workplace spirituality and organizational performance. Workplace Spirituality and Organizational Performance, 63(3), 355-363. https://doi.org/10.1111/15406210.00295 